\title{
Coronavirus and emergency management in Nigeria
}

\author{
Ejiroghene A. Oghuvbu ${ }^{\circledR}$, Abraham E. Orhero ${ }^{(D)}$, Ugo C. Okolie \\ Delta State University, Abraka, Nigeria \\ $\bowtie$ augustine4best@yahoo.com
}

\begin{abstract}
Relevance.This study examines the efforts of the Nigerian government towards managing the coronavirus infection. COVID-19 is an infectious disease that originated from Wuhang, China at the end of 2019. In the early stages, the virus infected about 300 people and caused the deaths of six people. Despite early detections and reactions by the Chinese government, the disease spread to the different countries of the world. By June 2021 more than 170 million (170,000,000) people have been infected with the disease with more than three million and sixty thousand $(3,600,000)$ deaths. According to Johns Hopkins University in Nigeria, in June 2021, 167 thousand cases of diseases and more than 2 thousand deaths were registered. Materials and Methods. The study analyses data from open sources such as academic journals, books, newspapers and online sources. Results and Discussion. Findings of the study reveal that while the actions of the Nigerian government have been preventive, they have not curtailed the spread of the virus. Conclusion. The researchers recommend that the Nigerian government intensifies its efforts towards to limit the spread of the virus by effectively implementing lockdowns and bans on public gatherings, improve testing capacities to identify and isolate carriers of the virus.
\end{abstract}

Keywords: Coronavirus, COVID-19, Emergency Management, Nigeria

Author contributions. The authors made an equivalent contribution to the publication.

Conflict of interest statement. The authors declare no conflict of interest.

Received 29.04.2021. Accepted 11.06.2021.

For citation: Oghuvbu EA, Orhero AE, Okolie UC. Coronavirus and emergency management in Nigeria. RUDN Journal of Medicine. 2021;25(3):196-201. doi: 10.22363/2313-0245-2021-25-3-196-201

(C) Oghuvbu E.A., Orhero A.E., Okolie U.C., 2021

This work is licensed under a Creative Commons Attribution 4.0 International License https://creativecommons.org/licenses/by/4.0/ 


\section{Introduction}

The world has witnessed a number of health emergencies and pandemics ranging from the Spanish flue to the Hong Kong flu, Ebola, Zika, Severe Acute Respiratory Syndrome (SARS), Acquired Immunodeficiency Syndrome (AIDS), and Influenza among others [1]. The most recent of such issues is the coronavirus pandemic. The Coronavirus COVID-19 is an infectious disease that originated from Wuhang, China in the latter part of 2019 [2]. In the early stages, the virus infected about 300 people and caused the deaths of six people [3].

Despite early detections and reactions by the Chinese government, the disease spread to the different countries of the world. By June 2021 more than 170 million $(170,000,000)$ people have been infected with the disease with more than three million and sixty thousand $(3,600,000)$ deaths. [4]. Along with these Fig.s, more than hundred million $(100,000,000)$ people have recovered from the virus. Countries most affected by the pandemic include the United States, Italy, Spain, the United Kingdom, France, Netherlands, Iran, South Korea, Malaysia, Thailand, among others [5, 6]. Nigeria is also affected by the pandemic. According to Johns Hopkins University in Nigeria, in June 2021, 167 thousand cases of diseases and more than 2 thousand deaths were registered. While in February 2020, recorded cases in the country were at 1,095 with 208 discharged and 32 deaths [7].

In such situations, emergency management is significant and necessary to mitigate the adverse effects of the virus. In terms of studies, only few have been conducted. Ameh [8] investigates the global socioeconomic imports of the corona virus with a view of proffering policy solutions. From another perspective, the United Nations Conference on Trade and Development (2020) considers the impact of the Corona virus pandemic on global trade. While these studies abound, no study examines of the Nigerian government towards managing the pandemic within its borders. As a result, this study seeks to examine the efforts of the Nigerian government, towards curtailing the spread of the virus.

This paper is organised into five parts: the introduction, which presents an overview of the issue, the objective of the study and gaps identified in literature, the literature review which involves the clarification of concepts, and the review of relevant literature. The third section outlines the methodology employed in the study. The fourth section is the discussion with thematically organises data retrieved in line with the objectives of the study. The fifth section presents the recommendations and conclusions of the study.

\section{Coronavirus pandemic}

The Coronavirus otherwise known as the COVID-19 pandemic is an issue confronting states in the international system. It is a disease perturbing the nations of the earth by infecting large amounts of people. Its origins are traceable to a popular live animal market in Wuhan, China where numerous cases were identified in December of 2019 [2]. At the initial stages, about 300 people were infected by the virus, out of which six died in Wuhan [3]. However, on the 13th of January 2020, the first index case of the disease was recorded outside China, in Thailand. The patient was a returnee from Wuhang, China [9]. The contagious nature of the disease, made it possible for large numbers of people to be infected in a short period of time. In February, the number of recorded cases had risen from a few hundreds to about 81,000 cases out of which China at the time had 78,191 of the cases recorded [4]. The increasing number of cases forced the World Health Organisation to declare the health crisis a pandemic.

By April 2020, more than a million cases were reported worldwide with approximately 62,000 deaths [4]. As a result of the absence of vaccines and few means of treatment, countries have instituted preventive approaches to stem any increase of more cases. Such measures include partial or total lockdown, social and physical distancing measures and restrictions on travel, work, leisure and gatherings [10]. Countries such as the United States, Italy among others instituted varying degrees of lockdowns and restrictions due to the number of recorded cases [11].

\section{COVID-19 in Nigeria}

African countries are however not immune from the spread of the virus. South Africa, Ghana, Ivory 
Coast, Senegal and so on have reported index and active cases of the virus. In the case of Nigeria, the first case of the virus was identified in February 2020 when an infected Italian citizen arrived the country from Italy. After showing mild symptoms of the disease, the patient was promptly isolated and treated for the expressed symptoms [12].The number of cases increased to 132 by March 29, 2020 with 1 death. Part of those infected include public office holders such as Governors Bala Mohammed and Seyi Makinde of Bauchi and Oyo States respectively, and Malam Abba Kyari, who subsequently was killed due to complications relating to the disease [13]. The number of cases grew to 493 cases with 159 recovered and about 17 deaths [14]. As a result of the increasing number of cases recorded within its borders, the Nigerian government was forced to institute varying degrees of lockdowns in Lagos, Abuja and Ogun states, which are the epicentres of the Coronavirus [15]. Other states like Rivers, Delta, and Edo instituted varying degrees of lockdown to curb the spread of the virus.

\section{The concept of emergency management}

Emergencies are unexpected events that happen with little or no warning. Noteworthy, is the fact that no country, community or individual is immune to such occurrences. Such events bear with them a broad range of consequences and as such demand preparedness in terms of organizational readiness, coordination and communication among all partners involved [16]. In the matter of definitions, a plethora of explanations on the concept of emergency management subsist. Emergency management involves the process of responding to an undesired situation to mitigate adverse consequences. In more simple terms, emergency management involves risk aversion or minimization [17]. The process of emergency management also involves the process of managing natural and technological catastrophic events [18]. From the preceding, this study defines emergency management as the process of confronting unwanted circumstances, situations and events for the purpose of preventing and mitigating damage.

Emergency management comprises of four major elements, namely: mitigation, preparedness, response and recovery [19]. Mitigation as an element of emergency management involves reduce the exposure to risks or hazards [20]. With the occurrence of ill-fated events and happenings, there is a need to reduce the dangers that exist for the purpose of saving lives. The mitigation element of emergency management ensures this happens. This snowballs into the second element of emergency management, preparedness. In this context, preparedness involves alleviating the sufferings of human actors when disasters occur. Broadly, preparedness involves two distinct approaches, short term preparedness and long term preparedness [21]. The long-term approach of preparedness involves a permanent action plan, to settle and/or resettle victims of a disaster permanently. While the short-term approach involves activities such as relief operations and so on. According to Adams [22], response as an element in emergency management involves reacting to a situation with the appropriate attention and resources. In its entirety, emergency response involves, repeated assessment, planning, action and the review of actions to respond adequately to the needs of the victims of disaster. Recovery is the last stage of emergency management. In the words of Baird [23], the recovery element in emergency management involves the decisions and actions related to rebuilding and replacing homes and properties, resuming employment and so on. It involves, getting a society which has previously experienced disasters, back on track.

\section{Emergency management in Nigeria}

For any country including Nigeria, managing emergencies is an important task. Over the years, varying forms and degrees of emergencies and disasters have been identified in Nigeria. These include oil spills, pipe line vandalization, threat of desertification and pest infestation, epidemics like meningitis, avian influenza and the likes [24]. To effectively, manage such emergencies and disasters, the Nigerian government has overtime, developed policy and institutional frameworks [24]. One of the institutions charged with the responsibility of managing disasters in Nigeria is the National Emergency Management Agency (NEMA). Antecedents of NEMA trail back to 1972 when Nigeria 
experienced an overwhelming drought. This event had not only socio-economic consequences, but led to mass loss of lives in Nigeria. A response to such an occurrence by the then-government was the development of an agency that will effectively respond to emergencies in Nigeria. The agency named National Emergency Relief Agency (NERA) was formed in 1976 for the purpose of collecting and distributing relief materials to victims that had suffered one form of disaster or the other [25].

However, with regards to NERA, emergency management was limited as the scope of the agency only covered the provision of relief materials. It was not until 1993, that the government began efforts towards expanding the responsibilities of the agency. These efforts culminated into Decree 199 of 1993 which made NERA an independent agency under the presidency. Still citing its limited operations, the Nigerian government in 1999 through act 12 by the National Assembly, changed NERA to the National Emergency Management Agency (NEMA) and increased its responsibilities to managing emergencies [25]. NEMA, while managing emergencies, coordinates other institutions in doing so. This is to make sure the appropriate institution handles the right kind of emergency [26]. To ensure its effectiveness in handling disasters, NEMA with the approval of the government drafted series of plans on emergency and disaster management. These include the National Disaster Response Plan, the Search and Rescue/ Epidemic Evacuation Plan, the National Nuclear and Radiological Plan, Early Warning System on Epidemics, etc.

\section{Materials and methods}

This study employs the qualitative research method to investigate the Nigerian government's response to the COVID-19 pandemic within its borders. The study retrieves data from secondary sources notably academic journals, newspapers and online sources. The study employs thematic analysis to segment the data into themes in accordance with the objectives of the study.

\section{Results and discussion}

Nigeria in past times has expressed the ability to confront and curtail health crisis, disasters and pandemics. This is visible in the Ebola epidemic that ravaged African countries in 2014 [27]. However, in line with the scope of this study, there is a need to examine the response of the Nigerian government to the Coronavirus pandemic within its borders. The actions of the Nigerian government towards the COVID-19 pandemic within its borders are in the Table 1 [27-30].

Table 1

Nigeria's rection to the COVID-19 Pandemic

\begin{tabular}{|c|c|l|}
\hline S/N & DATE & \multicolumn{1}{c|}{ ACTION } \\
\hline 1. & $\begin{array}{c}\text { February 02, } \\
2020\end{array}$ & $\begin{array}{l}\text { Nigeria Centre for Disease Control (NCDC) issues } \\
\text { public health advisory to citizens, updating them } \\
\text { on the spread of the coronavirus }\end{array}$ \\
\hline 2. & $\begin{array}{c}\text { February 27, } \\
2020\end{array}$ & $\begin{array}{l}\text { Nigeria isolates the index case of coronavirus, } \\
\text { an Italian that arrived on the 25th of February } \\
\text { 2020 via a flight from Italy. }\end{array}$ \\
\hline 3. & $\begin{array}{c}\text { March 03, } \\
2020\end{array}$ & $\begin{array}{l}\text { Nigeria isolates contacts of the index case of } \\
\text { coronavirus at medical facilities }\end{array}$ \\
\hline 4. & $\begin{array}{c}\text { March 09, } \\
2020\end{array}$ & $\begin{array}{l}\text { President Muhammadu Buhari convenes } \\
\text { 12-member task force for the control of } \\
\text { coronavirus }\end{array}$ \\
\hline 6. & $\begin{array}{c}\text { March 19, } \\
2020 \\
2020\end{array}$ & $\begin{array}{l}\text { Nigeria suspends visa issuance on arrival for } \\
\text { travellers from China, United States of America, } \\
\text { United Kingdom among others. }\end{array}$ \\
\hline 7. & $\begin{array}{c}\text { March 30, } \\
2020 \\
2020\end{array}$ & $\begin{array}{l}\text { Nigeria bans all international flights due to the } \\
\text { increasing number of cases and also, shuts down } \\
\text { Lagos and Abuja airports. }\end{array}$ \\
\hline $\begin{array}{l}\text { Nigerian government institutes lockdown in } \\
\text { Lagos, Abuja and Ogun states as epicentres of } \\
\text { the coronavirus }\end{array}$ \\
\hline $\begin{array}{l}\text { Nigerian government extends the lockdown } \\
\text { in Lagos, Abuja and Ogun states due to the } \\
\text { increasing number of cases }\end{array}$ \\
\hline
\end{tabular}

Since February 2020, Nigeria has experienced increasing cases of COVID-19. Through the Nigeria Centre for Disease Control, Nigeria has been responding to the pandemic with preventive measures. However, these measures are preventive at best as they do not actively confront the spread of thevirus.Such measures include bans on international flights, lockdowns in Lagos, Abuja and Ogun states which have not been effective due to disobedience of stay at home orders and lack of social distancing measures in certain markets in the states [31]. Moreover, these measures were not implemented early enough. For example, the nonissuance of visas to arrivals at the airport and subsequent 
bans on international flights only occurred after the numbers of recorded cases had begun to grow. Such measures may not have been effective in stemming the spread of the Coronavirus in Nigeria.

\section{Conclusion}

This study examines the efforts of the Nigerian government towards managing the coronavirus within its borders. Nigeria overtime, has witnessed increasing numbers of cases. In response, the government has instituted varying degrees of lockdowns and preventive measures including lockdowns, closure of public places including schools, churches, mosques and bans on public gathering. The study identifies that these measures have been largely ineffective as the number of cases have been steadily increasing. Moreover, these measures were implemented after the number of recorded cases has become significant. In line with these, the study recommends that the Nigerian government intensifies its efforts towards curtailing the spread of the virus by effectively implementing lockdowns and bans on public gatherings, improve testing capacities to identify and isolate carriers of the virus.

\section{References}

1. Qu W, Rutherford S, Mao A, Chu C. The pandemic and its impacts. Health, culture and society. 2017;9-10.

2. Chen N, Zhou M, Dong X, Qu J, Gong F, Han Y, Zhang L. Epidemiological and clinical characteristics of 99 cases of 2019 novel Corona virus pneumonia in Wuhan, China: a descriptive study. The Lancet. 2020;395(10223):507-513.

3. Baker S. Everything we know about the mysterious, deadly Wuhan virus sweeping across China. Retrieved 2020; https://www.pulse.com.gh/bi/tech/everything-we-know-aboutthe-mysterious-deadly-wuhan-virus-sweeping-across-china/zd3sgq4

4. World Health Organisation. Virtual press conference on COVID-21 June 2021. World Health Organisation.

5. Davidson H. First COVID-19 case happened in November, China government records show - report. Retrieved 2020; https:// www.theguardian.com/world/2020/mar/13/first-COVID-19case-happened-in-november-china-government-records-show-report

6. Vara V. Corona virus outbreak: the countries affected. Retrieved 2020; https://www.pharmaceutical-technology.com/features/ Corona virus-outbreak-the-countries-affected/

7. Shaban ARA. Nigeria coronavirus cases at 981, Buhari gets ECOWAS mandate. Retrieved 2020; https://www.africanews. com/2020/04/24/nigeria-coronavirus-hub-updates-covid-19/
8. Ameh J. COVID-19: Buhari names 12-member presidential task force to control spread. Retrieved 2020; https://punchng.com/ covid-19-buhari-names-12-member-presidential-task-force-to-controlspread/

9. Aljazeera. Timeline: how the new Corona virus spread. Retrieved 2020; https://www.aljazeera.com/news/2020/01/timelinechina-Corona virus-spread-200126061554884.html

10. Warren K. Countries that are on lockdown because of the Corona virus. Retrieved 2020; https://www.pulse.ng/bi/lifestyle/ countries-that-are-on-lockdown-because-of-Corona virus/f28yp94

11. Onyeji E. Updated: Nigeria bans all international flights as coronavirus cases rise. Retrieved 2020; https://www.premiumtimesng. com/news/headlines/383095-updated-nigeria-bans-all-internationalflights-as-coronavirus-cases-rise-coronavirus-coronavirusinnigeriacoronavirusupdate-coronaviruspandemic.html

12. Ebenso B, Ou A. Can Nigeria contain the COVID-19 outbreak using lessons from recent epidemics? 2020; the Lancet Global Health.

13. Toromade S. A profile of all the cases confirmed in Nigeria, to be updated with new developments. Retrieved 2020; https://www.pulse. ng/news/local/Corona virus-timeline-and-profile-of-cases-in-nigeria/ k9p6lbk

14. Worldometer (2020). Total Corona virus cases in Nigeria. Retrieved from https://www.worldometers.info/Corona virus/country/ nigeria/ on the 13th of April 2020.

15. Ityokura M. Lockdown in Lagos, Abuja, others still on, says FG. Retrieved 2020; https://guardian.ng/news/lockdown-in-lagosabuja-others-still-on-says-fg/

16. Khorram-Manesh A. Introduction. In A. Khorram-Manesh, Handbook of Disaster and Emergency Management. 2017; Sweden: Institute of Clinical Sciences

17. Haddow GD, Bullock J A, Coppola DE. Introduction to emergency management. Amsterdam: Elsevier. 2011.

18. Waugh WL, Streib G. Collaboration and leadership for effective emergency management. 2006; Public Administrative Review, Special Issue.

19. Boston University. Emergency management. Retrieved 2020; from https://bu.edu/emergency-management-principles/

20. Sharifian S, Ghomian Z, Khodadadizadeh A, Jahangiri K. Assessment of Disaster Mitigation and Preparedness. Trauma Monthly, 2017;22(2):6.

21. Beura D. Preparedness programme in disaster management: a structural model. International Journal of Recent Scientific Research. 2016;7(11):14494-14497.

22. Adams J. Environmental health in emergencies and disasters: a practical guide. 2002; World health organization.

23. Baird ME. The recovery phase of emergency management. 2010; University of Memphis: Intermodal Freight Transportation Institute.

24. Isife CT, Ugwuany RO. Emergency Management and Disaster Risk Reduction as Tools for Sustainable Development in Nigeria. Journal of Environmental Management and Safety. 2012;3(4):57-71.

25. Essoh GE, Abutu, PO. Managing national emergency in Nigeria: prospects and challenges. Journal of Good Governance and Sustainable Development in Africa. 2018;4(1).

26. Adejokun S. NEMA, NOA and emergency management. Retrieved 2013; https://reliefweb.int/report/nigeria/nema-noa-andemergency-management. 
27. Courage KH. How did Nigeria quash its Ebola outbreak so quickly? Retrieved 2014; https://www.scientificamerican.com/article/ how-did-nigeria-quash-its-ebola-outbreak-so-quickly/

28. Adnan A. Nigeria ramps up response efforts to smash coronavirus: States shut schools, worship centres amid fears of the virus spreading. Retrieved 2020; https://www.aa.com.tr/en/africa/ nigeria-ramps-up-response-efforts-to-smash-coronavirus/1771922

29. Nigeria Centre for Disease Control. 3rd February 2020| Public health advisory to Nigerians on Novel Coronavirus (\#3). Retrieved
2020; https://ncdc.gov.ng/news/222/3rd-february-2020 \%7C-publichealth-advisory-to-nigerians-on-novel-coronavirus-\%28 \%233 \%29.

30. Adeniran I. Coronavirus: Two foreigners in Nigeria test negative. Retrieved 2020; https://www.premiumtimesng.com/regional/ ssouth-west/379976-coronavirus-two-foreigners-in-nigeria-testnegative.html

31. Oyero K. Lockdown not effective-Lagos speaker. Retrieved 2020; https://punchng.com/lockdown-not-effective-lagos-speaker/.

\title{
Коронавирусная инфекция и экстренные меры в Нигерии
}

\author{
Э.А. Огувбу ${ }^{\square}$, А.Э. Оргеро $^{\mathbb{D}}$, У.Ч. Околи \\ Государственный университет Дельта, г. Абрака, Нигерия \\ $\checkmark$ augustine4best@yahoo.com
}

\begin{abstract}
Аннотация. Актуальность. В исследовании изучаются усилия правительства Нигерии по борьбе с коронавирусной инфекцией. COVID-19 - это инфекционное заболевание, которое появилось в Китае, в городе Ухань, в конце 2019 года. На ранних стадиях вирус заразил около 300 человек и стал причиной смерти шести человек. Несмотря на ранние обнаружения и реакцию китайского правительства, болезнь распространилась по разным странам мира. На июнь 2021 года более ста семидесяти миллионов $(170,000,000)$ человек инфицированы этим заболеванием, более трех миллионов шестисот тысяч $(3,600,000)$ умерли. Согласно данным Университета Джонса Хопкинса в Нигерии в июне 2021 г. зарегистрировано 167 тысяч $(167,000)$ случаев заболеваний и более 2 тысяч $(2,000)$ летальных исходов. Материалы и методы. В исследовании анализируются данные из открытых источников, в частности академических журналов, книг, газет и онлайн-источников. Результаты и обсуждение. Результаты исследования показывают, что, хотя правительство Нигерии предприняли меры профилактики заболеваемости, они не ограничили распространение вируса. Выводы. Исследователи рекомендуют правительству Нигерии активизировать свои усилия по предотвращению распространения вируса путем эффективного введения ограничений и запретов на публичные собрания, улучшения возможностей тестирования для выявления и изоляции носителей вируса.
\end{abstract}

Ключевые слова: коронавирус, COVID-19, экстренные меры, Нигерия

Вклад авторов: авторы внесли равный вклад в подготовку рукописи.

Информация о конфликте интересов. Авторы декларируют отсутствие конфликта интересов.

Поступила 29. 04. 2021. Принята 11. 06. 2021.

Для цитирования: Oghuvbu E.A., Orhero A.E., Okolie U.C. Coronavirus and emergency management in Nigeria // Вестник Российского университета дружбы народов. Серия: Медицина. 2021. Т. 25. № 3. C. 196-201. doi: 10.22363/23130245-2021-25-3-196-201

Corresponding author: Ejiroghene Augustine Oghuvbu, Assistant Lecturer of the Department of History and International Studies of Delta State University. 330106, Delta State University, Abraka, Nigeria. E-mail: augustine4best@yahoo.com

Oghuvbu E.A. ORCID 0000-0003-1422-3806

Orehero A.E. ORCID 0000-0002-7596-554X

Okolie U.C. ORCID 0000-0002-0448-2938

Ответственный за переписку: Эджирогене Августин Огувбу, доцент кафедры истории и международных исследований. Нигерия, 330106, г. Абрака, Государственный университет Дельта. E-mail: augustine4best@yahoo.com

Огувбу Э.A. ORCID 0000-0003-1422-3806

Оргеро A.Э. ORCID 0000-0002-7596-554X

Околи У.Ч. ORCID 0000-0002-0448-2938 